Драгана Валигурска

Универзитет у Новом Саду

Филозофски факултет

Катедра за славистику

dragana.spasic@ff.uns.ac.rs
УДК 821.161.1.09-31"18":821.163.41.09-31"19"

https://doi.org/10.18485/slavistika.2021.25.2.19

Оригиналан научни рад примљено 22.6.2021.

прихваћено за штампу 6.10.2021.

\title{
УЛОГА ОЧЕВА У ПАТОЛОШКИМ ПОРОДИЧНИМ ОДНОСИМА. НА ПРИМЕРИМА ДЕЛА КОРЕНИ Д. ЋОСИЋА И БРАЋА КАРАМАЗОВИ Ф. М. ДОСТОЈЕВСКОГ
}

Рад је посвећен испитивању приступа двају писаца, Ф. М. Достојевског и Д. Ћосића, проблему патолошких породичних односа у романима Браћа Карамазови и Корени, са акцентом на личност и улогу оца у њима. Након прегледа ранијих истраживања која потврђују идејну и формалну сродност поменутих стваралаца, истраживачки фокус се усмерава на проблем урушавања патријархалне породице у другој половини дветнаестог века и његово представљање у оквиру књижевноуметничке стварности романа. Усмереност писаца на различите аспекте стварности, историјско-социјални код Ћосића, те метафизички код Достојевског, обезбедиле су својеврсне специфичности у осликавању породичних односа, као што је, на пример, Ћосићев акценат на трагичности положаја српске сељанке и мизогеним тенденцијама укорењеним у свести сељака. Породице Катић и Карамазов изједначава недостатак мајчинског начела, услед чега тема очинства, те удаљеност очева од традиционалног и хришћанског идеала оца као моралног узора иступају на први план.

Кључне речи: Браћа Карамазови, Корени, Ф. М. Достојевски, Д. Ћосић, породица, улога оца, очинство.

This article discusses ideological kinship between two writers, F. M. Dostoevsky and D. Cosić, in their approach to the problem of pathological family relations in the novels The Brothers Karamazov and The Roots, with an emphasis on the personality and the role of the father. Earlier studies on the subject confirm the ideological and formal similarity of the mentioned authors in general, so the research attention in the paper is mainly focused on the problem of the collapse of the patriarchal family in the second half of the $19^{\text {th }}$ century and its presentation in the novels. The writers' focus on various aspects of reality, social-historic in Ćosić's novel, and metaphysical in Dostoevsky's, provided the specifics in depicting family relations, such as emphasis on the tragedy of the Serbian peasant woman and misogynistic tendencies rooted in the peasant consciousness, as presented in The Roots. The Katic and Karamazov families are equated by the lack of a mother figure, as a result of which the topic of fatherhood and the distance of the fathers from the traditional and Christian ideal of the father as a moral role model come to the fore.

Keywords: The Brothers Karamazov, The Roots, F. M. Dostoevsky, D. Cosić, collapse of the patriarchal family, fatherhood.

Истраживање утицаја заоставштине Достојевског на потоње писце комплексан је задатак. Нарочито ако имамо у виду да последице тог деловања, поред тога што се могу манифестовати у разним смисаоним и структурним плановима књижевног дела, нису јавне и лако уочљиве. Уткани у нови уметнички свет, мотиви, идеје или пак перспектива из које се сагледавају вечита питања људског постојања и светског поретка могу добити другачије рухо и интерпретацију. Присутност и снагу утицаја лика и дела Достојевског у домаћем културном простору и књижевности прве половине двадесетог века најисцрпније је пред- 
ставио Милосав Бабовић у својој студији Достојевски код Срба. Спроводећи анализу на стваралаштву писаца за које су постојале јасне индикације да су бивали инспирисани Достојевским, аутор је дошао до значајног закључка да је уплив најприметнији у домену мисли: „Наши писци чешће су преузимали филозофско-етичке ставове Достојевског, него мотиве и ликове“" (Бабовић 1961: 364). Стваралаштво Добрице Ћосића није обрађено у студији признатог професора Београдског универзитета, што је потпуно оправдано ако имамо у виду најпре строге критеријуме којима се водио Бабовић, а затим и кратак временски период између првог издања Ћосићевог романа (1954) и објављивања поменуте студије (1961).

До сличног закључка дошао је и историчар књижевности Василије Калезић, који је испитивао однос Добрице Ћосића према Достојевском, а затим је своја размишљања изнео у есејистичком облику (в. Kalezić 1973). Из тог извора сазнајемо да су педесетих и шездесетих година, у критичким одзивима на стваралаштво Ћосића, навођени низови сродности са другим писцима, те да је Достојевски био препознат као узор, међутим без примера конкретизације. Не доводи се у питање Ћосићево познавање идејно-етичких концепција које карактеришу стваралаштво Достојевског, а као основну повезујућу нит два писца наводи идеју о злу у човеку и свету, односно да је „stvarno i potencijalno zlo imanentno čoveku uopšte" (Kalezić 1973: 48). Калезић инсистира на неоспорној духовној сродности управо у роману Корени, где проналази сличности не само у идеји, већ и у књижевним поступцима: разоткривању психолошке мотивације и унутрашњим осветљавањима сукоба у самом човеку. Аутор поменутог рада у свом истраживању обухвата низ Ћосићевих романа, тражећи у њима одјек Достојевског, те на тај начин ствара тек општу слику о сродности два писца, и оставља простор за даља, усмеренија истраживања. Ослањајући се на наведене закључке и сазнања, у даљем тексту приступићемо испитивању приступа двају писаца проблему распада патријархалне породице у романима Браћа Карамазови и Корени.

Иако је Ћосићев роман настао након нешто више од седамдесет година од тренутка објављивања последњег романа петокњижја, уочава се подударност у погледу временског оквира радње оба романескна света, што доприноси утемељености поређења једног феномена у делима различитих епоха. Достојевски се у свом стваралштву у неколико наврата обраћао теми породичних односа, како у романима (Зли дуси, Младић, Браћа Карамазови), тако и у Дневнику писца (1876-1877, 1880-1881), дефинишући различите тезе на који се овај сложени проблем може рашчланити, као што су, између осталог, случајност породице, затим, губитак њеног васпитног и заштитничког карактера у односу према деци, недовољност ангажовања оца у процесу подизања потомства или устаљеност окрутних пракси према деци. Познавање наведене литературе, односно вишеструкости перспектива из којих писац сагледава процес распада породице као јединствене и сврсисходне целине свакако нам могу помоћи да сагледамо и разумемо чиниоце које дефинишу односе унутар случајне породице Фјодора Павловича. Познато је да је писац овим термином означио породицу у којој, за разлику од свете породище, не влада узајамна љубав и поштовање, већ разједињеност и хаос. „Nikada ruska porodica nije bila 
više uzdrmana, podložna raspadanju i neoformljena kao što je to danas slučaj”, пише Достојевски у свом дневнику из 1877 . године, „Savremena ruska porodica postaje sve više i više slučajna porodica" (1982: 210).

Управо разједињеност, односно ослабљене (прекинуте) породичне везе можемо означити као најочигледнији елемент који повезује породице Карамазов и Катић. Уочавамо да се у оба случаја, у третнутку одигравања радње, породице приказују у њеном окрњеном и једнополном облику: чине је отац и одрасли синови, а мајке су покојнице. Наравно, у роману Корени постоји сложенији, вишегенерацијски модел породице, међутим, ми ћемо се усредсредити на породичну драму која се одвија на релацији између Аћима Катића и двојице његових синова, Вукашина и Ђорђа. Законити синови Фјодора Павловича остали су без мајке у раном детињству, а отац их је занемарио и препустио бригу о њима добротворима, услед чега су они при живом оцу добили статус сирочади. Недостатак мајчинског начела свакако дефинише и односе у кући Аћима Катића, где се личност мајке Живане тек назире у сећањима синова у понеким саветима и сликама. Из поменутих фрагмената ствара се лик слабашне, тихе и измучене жене, која се не супротставља правилима суровог патријархата - у складу са култом женског мучеништва и покорности. Колико је мајка могла имати утицаја у доношењу важних одлука око васпитања деце можемо закључити имплицитно на основу положаја који у кући Катића има Симка, Ђорђева жена: „жена говори само кад је муж пита и кад су у кревету” (Ћосић 1962: 33). Уосталом, чини се да су ликови Живане, Симке или Анђе само различите реализације једне протојунакиње - српске сељанке са краја деветнаестог и почетка двадесетог века, о чијој је трагичности писац говорио у књизи Славољуба Ђукића: „Нема те мученице која је равна сељанки. Нема тог социјалног понижења равног понижењу сељанке: емоционално, радно, биолошки. Патила је од мужа, од целокупне фамилије, од кухиње, од стоке од земље” (1989: 17). Занимљиво је да се „женско”, односно, све што је женског рода, доводи у везу са рђавим, изопаченим и непожељним. „Мени наследник треба... Женско... па зет да ми пролумпује и растури имање... Мрзим женско. Све што је женско... Мрзим и краву и овцу и кобилу. Не! Женско за ноге па о дирек” (Һосић 1962: 200). Не мањка примера којима се може потврдити последња теза, будући да се ради о мотиву који прожима читав текст. Оваквих, изразито мизогинистичких тврдњи нема у руском тексту, али зато нема ни сеоског менталитета, нити су социјално-историјске реалије у првом плану. Иако писце непобитно спаја тежња за приказивањем унутрашњег живота човековог бића и његово страдање, није згорег, у овом контексту, нагласити различитост приповедачког фокуса писаца када је у питању вид реалности која се осликава у роману. Наиме, Корени Добрице Ћосића нуде читаоцу увид у „историјску слику србијанског 19. века" (Михајловић 1988: 216), у реалије објективног уређења живота какав је био пре готово два века, борбе традиционално и проевропски оријентисаних политичких врхова, сукобе сеоског и градског менталитета, те приказује положај како мушкарца, тако и жене, у селу као најјачем упоришту патријархалних вредности. И ми ту историјску слику, иако је уметнички обликована, неоспорно доживљавамо као истиниту, будући да и данас препознајемо многе од њених елемената у својој садашњици. Са друге 
стране реалност коју препознајемо у стваралаштву Достојевског, укључујући и роман Браћа Карамазови, произилази у првом реду из слоја метафизичког:

„Čitava umetnost Dostojevskog govori o najdubljoj duhovnoj realnosti, o metafizičkoj realnosti; Ona se najmanje zanima za empirijske oblike života. (...) Kroz spoljašnju fabulu koja podseća na neverovatne kriminalne romane, prosijava druga realnost. Nisu realnosti empirijskog, svakodnevnog, životnih uslova i ukorenjenih tipova ono što je realno kod Dostojevskog. Realna je kod njega čovekova duhovna dubina, realna je i sudbina ljudskog duha. Realni su kod njega odnosi čoveka i Boga, čoveka i đavola; realne su kod njega ideje pomoću kojih čovek živi." (Berđajev 1982: 253)

Недостатак, односно негирање улоге мајке ставља у први план идеју очинства и улогу оца у одгоју потомака. У посматраним романима централни ликови очева припадају негативном типу јунака, категорији којој према дефиницији Н. Милошевића припадају књижевни јунаци чије моралне карактеристике не импонују читаоцима, али који могу имати позитивна интелектуална и психичка облежја (1990: 5). Дакле, негативну обојеност јунаци завређују пре свега кршењем етичких принципа, што се у извесном смислу може изједначити и са оглушавањем о божје заповести. На први поглед, ради се о књижевним ликовима потпуно различитих психолошких караткеристика. Док се Фјодор Павлович осликава као тип сладострасника, ниског и развратног човека, бестидног лакрдијаша, Аћим Катић је сељачки и радикалски вођа, посланик који до свог угледа држи више него до породице; први не даје на значају ни прошлости нити будућности, заокупиран једино задовољавањем својих тренутачних потреба, док другог у многоме одређује породична хроника, комплекс због свог дошљачког порекла и одрастања на Василијевом огњишту. Међутим, и Фјодор Павлович, ситан поседник и готован, као и Аћим Катић, апсолутни господар Прерова, изједначавају се на плану одговорности за дегенеративне односе унутар својих породица. Обојица су подједнако удаљени од хришћанског идеала оца као моралног узора и заповести љубави према ближњима. Унутарње порицање духовности манифестује се и у спољшњим сукобима са оцима у манастиру, мантијашима, како их назива Аћим Катић, изругивању туђим религијским осећањима и профанацијом (Достојевски, 2007: 111; Ћосић, 1962: 243)

Познато је да је у свим цивилизацијама, у традиционалним биолошким, психолошким, философским, социјалним и религиозним релацијама, улога оца посебно наглашена, не само са тачке гледишта генетског, већ и духовног наследства (Косановић 2010: 51). Тема наследства има двојаку конатацију у романима: док је материјално наследство и право на њега предмет расправе у односу између очева и синова, духовно наследство је очигледно и непобитно. Кочијаш у Вукашину препознаје Аћимову крв, а синови Фјодора Павловича признају своју карамазовску необузданост, стихијност, нискост, али и љубав према животу. Овај феномен је нарочито интересантан на примеру законитих синова Карамазова, за чије васпитање отац не преузима одговорност, задржавајући се тек на улози биолошког оца. Чак и Аљоша, којег семе добра, што му је усади- 
ла мати, води у манастир, и који проналази духовног оца у лику старца Зосиме, и он ће за себе рећи „Ах, ви не знате, и ја сам Карамазов!” (Достојевски, 2007: 175). Па ипак, иако су Митја, Иван и Аљоша рођењем обележени карамазовштином, одрастање у туђим кућама сачувало их је од деструктивне изложености очевом неподобном начину живота. Доказ за ову тезу налазимо у изопаченој природи четвртог, ванбрачног сина Фјодора Павловича, који је одрастао као слуга у очевој кући, дакле у његовој непосредној близини. Павла Фјодоровича Смердјакова, који у одраслом добу оваплоћује Иванове идеје и убија оца, од детињства карактерише деструктивност, и склоност ка мучењу: „,У детињству је врло волео да веша мачке и после да их сахрањује по обреду" (Достојевски 2007: 100).

Аћима Катића, пак, одликује претерана суровост и саможивост; његова љубав према синовима у основи је егоистична. „А синове волиш као што се воле брзи коњи... кад су најбржи у селу. Волиш их само ако ти други завиде на њима." - замериће оцу Ђорђе (Ћосић 1962: 197). Отац од најранијег детињства прави разлику међу синовима фаворизујући млађег јер се видело да ће бити леп и крупан попут њега (Ћосић 1962: 44), чиме успоставља непремостиви јаз међу браћом. Не преза од психолошких, али ни физичких напада на укућане (Ћосић 1962: 79, 110). Осим тога склон је блудничењу и разврату (Ћосић 1962: 233), и „туђом руком” убија своје непријатеље и пали им куће: „Имао је снаге да једноме таквом оде у кућу и свећу му запали" (Ћосић 1962: 265). Уколико бисмо се водили поделом човечанства из једног другог романа Достојевског, рекли бисмо да он припада малобројној групи рушилаца који имају право, односно, наполеоновском типу. Иако је Аћим Катић починио озбиљне грехове, сасвим је сигурно да осваја веће симпатије читалаца од лакрдијаша Фјодора Павловича. Феноменом привлачне моћи негативних јунака бавио се Н. Милошевић, и његови закључци примењиви су и у овом случају. Морална одбојност Ћосићевог јунака неутрализована је осветљавањем његове људске, хумане стране. Поступком тока свести писац нам је пружио увид „изнутра” у све околности које су допринеле стварању изражене егоманије, у његову личну трауму, патњу и корене потребе да унуци носе презиме Аћимовић.

У роману Достојевског не примећујемо настојања писца да морално оправда Фјодора Павловича, нити се овај лик одликује нарочитом морфолошком сложеношћу, каква се, на пример, може уочити у ликовима његових синова. Још од Бахтинове студије познато је да књижевни јунак није интересовао Достојевског као појава стварности, као личност са фиксираним социјално-типичним и индивидуалним особинама, већ да се његова суштинска улога састоји у томе што је носилац посебног угла гледања на свет и себе самог: „Dostojevskom nije važno šta predstavlja njegov junak u svetu, već pre svega šta za njegovog junaka predstavlja svet, a šta on sam za samoga sebe" (Bahtin, 2010: 47). У складу са тим, узроке за неподобност Фјодора Павловича као оца не налазимо у социјално-типичном, односно традиционалном; његово неприхватање очинске улоге у складу је са његовим сладострашћем. Другачија је ситуација у Ћосићевом роману. Однос Аћима Катића према синовима умногоме одређују догађаји и личности који припадају прошлости. Садашњост и прошлост тесно су испреплетени у наративној структури романа, будући да се приповедно време 
прекида ретроспективним епизодама. Из сећања из детињства Аћима Катића извире читав свет сложених породичних односа, из којих се намеће закључак да је његово очинство условљено његовим синовством. „Аћиме, веруј само себи, и то кад си сам. Синови треба да те се плаше и помало да те мрзе док не остариш. Једино они и мајка могу да донесу несрећу човеку. А унуке воли" - једина је поука оца које се он сећа (Ћосић 1962: 44).

Једна од тема романа Браћа Карамазови јесте љубав у својим разним обличјима: родитеља према деци, деце према родитељима, човека према себи, другом човеку, Богу и човечанству. У каквом год се облику она испољавала, љубав се може поделити на истиниту и неистиниту. Уколико бисмо из те перспективе посматрали односе оца према синовима у роману Корени, љубав Аћима Катића сврстали бисмо у категорију неистините, лажне љубави, коју Достојевски означава појмом надрыв. Ово осећање карактерише секундарност, условљеност другим примарним осећањем које саставља суштину и одређује човеково понашање у кључним моментима. „Наизглед то може деловати као љубав према другом, а заправо је усмерена према самом себи" (превод Д. В.) (Линков 2008: 118). У коначном резултату, корен разједињености и несреће обеју породица лежи у егоизму оца, са једином разликом у његовој манифестацији. Деструктиван утицај на потомке, на њихово формирање личности може имати како одсуство оца у детињству - очинство је одговорност којег се човек не може одрећи - као и деспотски однос оца према потомцима, однос без нежности и прихватања. О томе сведочи и мисао Достојевског забележена у Дневнику: „Bez svega onoga što je sveto i dragoceno i što je dete za celi život ponelo iz detinjstva čovek ne bi mogao da živi”" (Достојевски, 1982: 210). И заиста, Ђорђе Катић, најтрагичнији лик у Ћосићевом роману, и у одраслом добу не може да превазиђе увреде нанете у детињству, грубо опхођење оца, или поређење са млађим братом, нити да се ослободи слика понижене, претучене и наге мајке. Као што Иван Карамазов, који је у најранијем добу схватио да је одбачен, да живи у туђој кући и да зависи од туђе милостиње, као одрастао човек сакупља приче о патњи деце, коју мучки шибају родитељи и растрзају пси. На њима он заснива своју побуну против Бога, која ће га напослетку одвести у болест.

У анализи представљања проблема дегенеративних односа унутар традиционалне породице у оквиру романа Браћа Карамазови и Корени утврдили смо да упркос неподударности приповедачког фокуса писаца по питању вида реалности који се осликава у романима, постоји низ идејних сродности у приступу писаца овом проблему, укључујући негацију мајчинског начела, наглашену одговорност очеве улоге у васпитању деце, утицај детињства на развој људске личности, као и егоизам очева као основни узрок ослабљених породичних веза.

\section{Цитирана литература}

Бабовић, Милосав. Достојевски код Срба. Титоград: Графички завод, 1961. [Babović, Milosav. Dostojevski kod Srba. Titograd: Grafički zavod, 1961.] Косановић, Богдан. Нове компаративне теме. Нови Сад: Филозофски факултет, 2011. [Kosanović, Bogdan. Nove komparativne teme. Novi Sad: Filozofski fakultet, 2011.] Линков, Владимир Яковлевич. История русской литературы XIX века в идеях. 
Москва: Изд-во Моск. Ун-та; «Печатные Традиции», 2008.

[Linkov, Vladimir Âkovlevič. Istoriâ russkoj literatury XIX veka v ideâh. Moskva: Izd-vo Mosk. Un-ta; «Pečatnye Tradicii», 2008.]

Михајловић-Михиз, Борислав. Портрети. Београд: Нолит, 1988.

[Mihajlović-Mihiz, Borislav. Portreti. Beograd: Nolit, 1988.]

Bahtin, Mihail. Problemi poetike Dostojevskog. Beograd: Zepter Book World, 2000.

Berđajev, Nikolaj. Duhovni lik Dostojevskog. Ruska religijska filozofija i F.M. Dostojevski. Ljubljana: Partizanska knjiga / Beograd: OOUR Izdavačko-publicistička delatnost Beograd, 1982.

Đukić, Slavoljub. Čovek u svom vremenu - Razgovori sa Dobricom Ćosićem. Beograd: Filip Višnjić, 1989.

Dostojevski, Fjodor M. Dostojevski kao mislilac. Knjiga 4. Dnevnik pisca : $1877-$ 1881, Ljubljana: Partizanska knjiga / Beograd: OOUR Izdavačko-publicistička delatnost Beograd, 1982.

Kalezić, Vasilije. Ćosić i Dostojevski. Novi kritički sporovi. Novi Sad: Prosveta, 1973. Milošević, Nikola. Negativan junak. Beograd: Vuk Karadžić, 1965.

\section{Извори}

Достојевски, Фјодор М. Браћа Карамазови. Београд: Отворена књига, 2007.

[Dostojevski, Fjodor M. Braća Karamazovi. Beograd: Otvorena knjiga, 2007]

Ћосић, Добрица. Корени. Београд: Просвета, 1962.

[Ćosić, Dobrica. Koreni. Beograd: Prosveta, 1962]

\section{Драгана Валигурска}

\section{РОЛЬ ОТЦОВ В ПАТОЛОГИЧЕСКИХ СЕМЕЙНЫХ ОТНОШЕНИЯХ. НА ПРИМЕРАХ РОМАНОВ БРАТЬЯ КАРАМАЗОВЫ Ф. М. ДОСТОЕВСКОГО И КОРНИ Д. ЧОСИЧА}

\section{Резюме}

Влияние творчества Достоевского на сербское культурное пространство и литературу первой половины XX века оказалось плодотворной темой в сербском литературоведении. Общую картину идейного сходства двух писателей, Ф. М. Достоевского и Д. Чосича, представил в своей работе В. Калезич, создав хорошую основу для дальнейших, более целенаправленных исследований. В предлагаемой работе анализируется проблема распада патриархальной семьи во второй половине XIX века и ее представление в литературно-художественной реальности романов Братья Карамазовы и Корни. В анализе патологических отношений внутри традиционной семьи в романах Братья Карамазовы и Корни мы указали на ряд идейных сходств в подходе писателей к этой проблеме, включая отсутствие или отрицание фигуры матери, влияние детства на последующее развитие личности и ответственность отца за воспитание детей, особо отметив при этом эгоизм отцов как основную причину ослабления семейных уз в обоих романах.

Ключевые слова: Братья Карамазовы, Корни, Ф. М. Достоевский, Д. Чосич, патриархальная семья, роль отца. 